\title{
GAMBARAN KEADAAN FASILITAS SANITASI DI PASAR KRENENG DESA DANGIN PURI KANGIN KECAMATAN DENPASAR UTARA TAHUN 2021
}

\author{
Putu Sintiya Marisa ${ }^{1}$, Anysiah Elly Yulianti ${ }^{2}$, Ni Ketut Rusminingsih ${ }^{3}$
}

\begin{abstract}
Poor market sanitation conditions can indirectly affect the health of the market occupants. This research was conducted at Kreneng Market, while this research was to describe the state of sanitation facilities in Kreneng Market including the state of clean water, the state of bathrooms and toilets, waste management, the state of the waste water disposal facilities, the state of the hand washing area and efforts to control vectors and infectious animals. disease. The research used a descriptive method with the results of this study, namely the state of clean water, the state of the bathroom and toilet, the state of SPAL, the state of the washing place which were categorized as having met the requirements in accordance with Permenkes No. 17 of 2020, while waste management and efforts to control vectors and animals that transmit diseases are categorized as not meeting the requirements. The suggestions that the author wants to give, namely the Kreneng Market managers are expected to maintain the state of clean water, state of the bathrooms and toilets, waste management, state of waste water disposal facilities, state of hand washing and control efforts of vectors and disease-transmitting animals, if possible to be improved again. To the traders in Kreneng Market, the author hopes to jointly with the market managers maintain the cleanliness of the market sanitation facilities.
\end{abstract}

Keywords: Sanitation, Market, Kreneng

\section{PENDAHULUAN}

Pada kawasan pasar terdapat berbagai unsur media lingkungan antara lain air, udara, tanah, pangan, sarana bangunan dan vektor yang dapat menjadi media penyebaran penyakit. Oleh karena itu diperlukan suatu upaya untuk mewujudkan kondisi kawasan pasar yang sehat, baik secara fisik maupun non fisik melalui pendekatan pasar sehat ${ }^{1}$. Pasar Kreneng merupakan salah satu pasar tradisional yang sangat dikenal masyarakat Bali khususnya warga Kota Denpasar.

Berdasarkan hasil pengamatan yang telah penulis lakukan menunjukkan bahwa keadaan fasilitas sanitasi seperti kamar mandi dan toilet yang tidak terawat dan berbau serta ditemukan adanya tikus yang berkeliaran di kios milik pedagang dan merusak barang jualan yang ada di kios tersebut. Sampah yang berasal dari sisa aktivitas 
pedagang yang masih berserakan di area pelataran dan tangga, ditemukan adanya lalat disekitar tempat pembuangan sampah.

Penelitian ini bertujuan untuk menggambarkan keadaan fasilitas sanitasi yang ada di Pasar Krenengmeliputi keadaan air bersih, keadaan kamar mandi dan toilet, pengelolaan sampah, keadaan sarana pembuangan air limbah, keadaan tempat cuci tangan, dan upaya pengendalian vektor dan binatang penular penyakit.

\section{METODE}

Jenis penelitian yang digunakan adalahpenelitian deskriptif dengan jenis data yang dikumpulkan yaitu data primer dan data sekunder. Teknik pengumpulan data yaitu dengan melakukan observasi menggunakan formulir penilaian sanitasi pasar dan wawancara menggunakan kuesioner yang ditujukan kepada pengelola pasar serta melakukan pengukuran pada item yang perlu diukur. Pelaksanaan penelitian ini berpedoman pada Permenkes No. 17 Tahun 2020 tentang Pasar Sehat, hasil dari penelitian dikategorikan menjadi dua kategori yaitu memenuhi syarat dan tidak memenuhi syarat.

\section{HASIL DAN PEMBAHASAN}

Berdasarkan hasil observasi keadaan air bersih di Pasar Kreneng dapat dikategorikan telah memenuhi syarat, hal ini sesuai dengan Permenkes No. 17 Tahun 2020 tentang Pasar Sehat yang menyatakan bahwa di dalam pasar harus tersedia air bersih dengan jumlah yang cukupdan mengalir lancar. Untuk keperluan higiene sanitasi, kran air terletak di tempat yang strategis dan mudah dijangkau, jarak sumber air bersih dengan pembuangan limbah minimal 10 meter,air yang digunakan harus bersih, tidak berwarna, tidak berbau, dan tidak berasa.

Pemeriksaan air di lapangan menunjukkan bahwa air yang digunakan telah memenuhi syarat hal tersebut dibuktikan dengan keadaan air tidak berwarna (jernih), air tidak berbau (dibuktikan dengan melakukan deteksi bau menggunakan hidung) dan air tidak berasa (dibuktikan dengan melakukan deteksi rasa menggunakan lidah). 
Pemeriksaan air dengan menggunakan panca indra ini didukung dengan teori yang dikemukakan oleh Kusnaedi (2004) yang mengemukakan bahwa syarat fisik air meliputi air tidak berwarna, air dikatakan memiliki kualitas yang baik apabila air tersebut tampak jernih. Air tidak berbau, air yang kualitasnya baik yaitu tidak berbau bila dicium dari dekat maupun jauh. Air yang menimbulkan bau busuk mengandung bahan organik yang mengalami penguraian oleh mikroorganisme air. Air tidak berasa, secara fisik air dapat dirasakan oleh indra perasa atau lidah. Air yang kualitasnya baik memiliki rasa yang tawar, kualitas air dikatakan buruk jika memiliki rasa asam, manis, pahit atau asin. Rasa asin diakibatkan adanya garam tertentu yang larut dalam air, rasa asam akibat dari adanya asam anorganik ataupun organik.

Pada penelitian ini, air bersih yang digunakan di Pasar Kreneng bersumber dari sumur gali, sumur gali adalah sarana penyediaan air bersih dengan cara mengambil atau memanfaatkan air dengan cara mengambil atau memanfaatkan air dengan mengambil air menggunakan tangan sampai mendapatkan air bersih. Penentuan lokasi penempatan sumur gali adalah sebagai berikut: (Joko, 2010) ditempatkan pada lapisan tanah yang mengandung air yang berkesinambungan, lokasi sumur gali berjarak horizontal minimal 11 meter ke arah hulu dari aliran air tanah dari sumber pencemar, seperti : bidang resapan dari tangki septic tank, kakus, empang, lubang galian sampah dan lain sebagainya, lokasi sumur gali terhadap perumahan bila dilayani secara komunal maksimal berjarak 50 meter, air yang ditampung dalam sumur adalah berasal dari akuifer, dan sumur tidak boleh kemasukan air banjir.

Berdasarkan hasil observasi dan pengukuran keadaan kamar mandi dan toilet di Pasar Kreneng, dikategorikan telah memenuhi syaratsesuai yang disebutkan di dalam Permenkes No. 17 Tahun 2020 tentang Pasar Sehat yang meliputi toilet harus bersih, tidak ada genangan air, tidak ada sampah, tidak berbau, kamar mandi dan toilet harus tersedia bak dan air bersih dalam jumlah cukup dan harus bebas 
jentik, di dalam toilet tersedia jamban leher angsa, peturasan, tersedia tempat cuci tangan dan di lengkapi sabun dan air mengalir, air limbah dibuang ke septic tank (multi chamber), riol atau lubang peresapan tidak mencemari air tanah dengan jarak 10 meter dari sumber air bersih, lantai dibuat kedap air, tidak licin, mudah dibersihkan dengan kemiringan sesuai ketentuan yang berlaku sehingga tidak terjadi genangan, letak toilet terpisah minimal 10 meter dengan tempat penjualan dan bahan pangan,pintu toilet tidak menghadap langsung dengan tempat penjualan makanan dan bahan pangan, mempunyai lubang angin atau ventilasi dan pencahayan minimal 100 lux, dan tersedianya tempat sampah yang tertutup.

Berdasarkan hasil observasi dan wawancara mengenai pengelolaan sampah di Pasar Kreneng, dikategorikan tidak memenuhi syarat. Hasil penelitian di lapangan tidak sesuai dengan yang tercantum di dalam Permenkes No. 17 Tahun 2020 tentang Pasar Sehat yang menyatakan bahwa pengelolaan sampah di pasar harus memenuhi persyaratan seperti mempunyai tempat penampungan sementara (TPS) yang kuat, kedap air, mudah dibersihkan, dan mudah dijangkau petugas pengangkut sampah, TPS tidak bau dan tidak ada sampah berserakan, TPS tidak menjadi tempat perindukan vektor penular penyakit, TPS memiliki akses jalan terpisah dengan jalur utama pasar, ada pemisahan sampah basah dan sampah kering, tersedia alat pengangkut sampah yang kuat mudah dibersihkan dan mudah dipindahkan, sampah diangkut minimal 1x24 ke tempat pemrosesan akhir (TPA), tersedia tempat sampah di setiap kios, los, lorong pasar. Tempat sampahterbuat dari bahan kedap air, tidak mudah berkarat, kuat, tertutup dan mudah dibersihkan, dan adanya pengelolaan sampah dengan metode 3R (reduce, reuse, recycle).

Berdasarkan karakteristiknya sampah yang dihasilkan di Pasar Kreneng terdiri dari sampah organik dan sampah anorganik (botol plastik, kardus) maka dari itu perlu dilakukan upaya pemilahan sampah langsung pada sumbernya, setelah dilakukan pemilahan kemudian dilakukan 
pengelohan sampah. Sampah organik dapat diolah menjadi pupuk organik dengan sistem komposting untuk selanjutnya dimanfaatkan dibidang pertanian, hal ini didukung oleh penelitian yang dilakukan oleh Jana dkk (2006)yang menyatakan bahwa pemanfaatan sampah pasar sebagai bahan baku kompos berarti telah mampu mereduksi beban sampah sebesar $24 \mathrm{~m}^{3} /$ hari. Hal ini dapat mengurangi sampah yang masuk TPA sehingga dapat menghemat lahan, mengurangi biaya operasional serta dapat diperoleh keuntungan berupa pupuk organik sebagai hasil akhir. Sementara untuk sampah anorganik (botol plastik dan kardus) dapat didaur ulang menjadi barang yang bernilai guna.

Fakta lain di lapangan menunjukkan bahwa di tempat penampungan sementara telah tersedia bak penampungan sampah organik dan anorganik namun masih belum dimanfaatkan dengan efektif, masih ditemukan sampah yang digabungkan antara sampah organik dan anorganik. Sementara itu dimasing-masing kios pedagang hanya menggunakan kantong plastik untuk menampung sampah, hal tersebut tentu tidak sesuai dengan persyaratan yang ada di dalam Permenkes No. 17 Tahun 2020 tentang Pasar Sehat.

$$
\text { Tempat penampungan }
$$

sampah (TPS) menjadi tempat perindukan lalat, hal tersebut dibuktikan dengan adanya lalat di kawasan TPS dan ditemukan adanya tumpukan sampah di sudut tangga serta sampah yang berserakan di area pasar. Noviyani dkk (2018) mengemukakan bahwa berseraknya sampah di area pasar dapat menimbulkan adanya lalat yang berada di sekitar sampah dan tidak menutup kemungkinan lalat tersebut membawa permasalahan dalam kesehatan masyarakat atau membawa bakteri atau kuman penyebab penyakit pada masyarakat seperti diare.

Berdasarkan hasil observasi keadaan sarana pembuangan air limbah di Pasar Kreneng, dikategorikan memenuhi syarat. Fakta di lapangan menunjukkan kesesuaian dengan yang tercantum di dalam Permenkes No. 17 Tahun 2020 tentang Pasar Sehat yang menyatakan bahwa saluran limbah cair/drainase disemen dan di tutup 
dengan kisi kisi dari logam dilengkapi bak kontrol/ tertutup tidak permanen, limbah toilet (black water) dialirkan langsung ke septic tank, aliran air limbah cair lancar, tidak ada bangunan di atas saluran, tidak ada genangan air limbah di dalam pasar.

Kendati demikian pihak pengelola mengatakan bahwa limbah cair (grey water) yang berasal dari setiap $\operatorname{los}$ daging/ikan/ayam/dapur/tempat pencucian peralatan, tempat cuci tangan dan kamar mandi disalurkan langsung ke saluran pembuangan umum dan belum tersedia instalasi pengolahan air limbah (IPAL). Adanya Instalasi Pengolahan Air Limbah(IPAL) yang bertujuan untuk menghilangkan bahan-bahan tersuspensi dan terapung, mengurangi organisme patogen yang terkandung dalam limbah cair.

Keberadaan IPAL di suatu pasar sangat penting mengingat air limbah yang dihasilkan mengandung mikroorganisme patogen dan bahan berbahaya yang dapat mencemari lingkungan maka dari itu diperlukan proses pengolahan limbah menggunakan IPAL, pernyataan ini didukung oleh teori yang dikemukakan oleh Sumantri (2013)yang berpendapat bahwa prosespengolahan IPAL dikelompokkan sebagai pengolahan pertama (Primary treatment) yang bertujuan untuk memisahkan padatan dari air secara fisik menggunakan saringan/filter, pengolahan kedua (secondary treatment) yang bertujuan untuk mengurangi bahan organik dan menghilangkan nutrisi seperti nitrogen dan fosfor, dan pengolahan lanjutan (tertiary treatment) bertujuan untuk menghilangkan nutrisi/unsur hara khususnya nitrat dan posfat, juga sebagai pemusnahan mikroorganisme patogen.Melalui tahapan pengolahan tersebut maka limbah yang dihasilkan oleh pasar dapat dibuang dengan aman tanpa mencemari lingkungan.

Berdasarkan hasil observasi keadaan tempat cuci tangan di Pasar Kreneng, dikategorikan memenuhi syarat. Hasil penelitian di lapangan telah sesuai dengan Permenkes No. 17 Tahun 2020 tentang Pasar Sehat yang di dalamnya tertera bahwa tersedia tempat cuci tangan dengan air mengalir dengan jumlah yang 
cukup, dilengkapi sabun, dijaga kebersihannya dan terletak di lokasi yang mudah terjangkau, tersedia minimal di pintu masuk dan keluar pasar serta toilet, dan tersedia di setiap los.

Pada tahun 2020, telah terjadi pandemi COVID-19dimana virus tersebut telah menyebar di seluruh dunia, termasuk Indonesia.COVID19 disebabkan oleh virus (SARS$\mathrm{CoV}$-2) yang merupakan bagian dari coronavirus. Virus tersebut menyebar melalui kontak langsung dengan tetesan cairan pernapasan (droplet) orang yang terinfeksi (dihasilkan melalui batuk dan bersin).Dalam situasi wabah, CTPS merupakan perilaku sederhana namun sangat efektif dalam melindungi kesehatan masyarakat termasuk mencegah penularan virus corona. Untuk membudayakan perilaku cuci tangan pakai sabun maka harus tersedia sarana CTPSyang memiliki kriteria utama yaitu air bersih yang dapat dialirkan, sabun dan penampungan atau saluran air limbah yang aman.

Berdasarkan hasil observasi dan wawancara, upaya pengendalian vektor dan binatang penular penyakit di Pasar Kreneng dikategorikan tidak memenuhi syarat, hal ini tentu tidak sesuai dengan Permenkes No. 17 Tahun 2020 tentang Pasar Sehat menyatakan bahwa persyaratan pengendalian vektor dan binatang penular penyakitdapat dilakukan penyemprotan lalat, nyamuk, kecoa dan tikus setiap bulan, los makanan siap saji dan bahan pangan harus bebas dari lalat, kecoa dan tikus, tidak ada binatang tikus, kucing, anjing yang berkeliaran di dalam pasar, dan adanya pemantauan lalat, nyamuk, kecoa dan tikus secara berkala minimal dua kali setahun.

Fakta di lapangan menunjukkan bahwa masih ditemukan adanya tikus yang berkeliaran di area pasar termasuk di dalam kios milik pedagang yang menimbulkan kerusakan pada barang dagangannya, keberadaan tikus di area pasar berpotesi menularkan penyakit yang dapat mengganggu kesehatan manusia.

$$
\begin{aligned}
& \text { Menurut Ristiyanto dkk } \\
& \text { (2002) mengatakan bahwa jenis } \\
& \text { penyakit yang dibawa oleh tikus } \\
& \text { antara lain pes, leptospirosis, murine } \\
& \text { typhus, scrub typhus, leishmaniasis, } \\
& \text { salmonellosis, penyakit chagas dan }
\end{aligned}
$$


juga beberapa penyakit cacing seperti schistosomiasis dan angiostrongyliasis. Penyakitpenyakit tersebut juga ditularkan melalui ektoparasit yang ada di tubuh tikus.

Berdasarkan hasil wawancara, pihak pengelola Pasar Kreneng menyatakan bahwa belum pernah melakukan penyemprotan terhadap lalat, nyamuk, dan kecoa di setiap bulan dan juga belum pernah melakukan pemantauan lalat, nyamuk, kecoa dan tikus secara berkala minimal 2 kali setahun.

Keberadaan tikus di suatu tempat dapat diketahui dengan adanya:Dropingyaitu adanya kotoran tikus yang ditemukan di tempat atau ruangan yang diperiksa. Tinja tikus mudah dikenali dari bentuk dan warna yang khas tanpa disertai bau yang mencolok, tinja yang masih baru lebih terang, mengkilap, serta lebih lembut. Semakin lama tinja akan semakin keras ${ }^{8}$, Run waysyaitu jalan yang biasa dilalui tikus dari waktu ke waktu di suatu tempat. Tikus mempunyai kebiasaan melalui jalan yang sama, bila melalui lubang diantara eternit rumah, maka jalan yang dilaluinya lambat laun akan menjadi hitam ${ }^{9}, \quad$ Grawingadalah bekas gigitan yang dapat ditemukan. Tikus dalam aktivitasnya akan melakukan gigitan untuk makan maupun membuat jalan, misalnya lubang dinding 9 , Borrow adalah lubang yang terdapat pada sekitar beradanya tikus seperti dinding, lantai, perabotan, dan lain-lain ${ }^{10}$, dan Bau yang disebabkan oleh tubuh tikus atau urinnya. Tempat ditemukannya tikus hidup yang berkeliaran di suatu tempat atau tempat ditemukanya bangkai tikus baru atau lama juga dapat menjadi pertanda keberadaan tikus ${ }^{10}$.

\section{SIMPULAN DAN SARAN}

\section{Simpulan}

Berdasarkan hasil penelitian dan pembahasan di atas maka dapat diambil simpulan sebagai berikut:keadaan air bersih di Pasar Kreneng telah memenuhi syarat, keadaan kamar mandi dan toilet yang ada di Pasar Kreneng telah memenuhi syarat, pengelolaan sampah di Pasar Krenengdikategorikan tidak memenuhi syarat, keadaaan sarana pembuangan air limbah di Pasar Kreneng telah memenuhi syarat, 
keadaan tempat cuci tangan yang ada di Pasar Kreneng telah memenuhi syarat dan upaya pengendalian vektor atau binatang penular penyakit di Pasar Kreneng tidak memenuhi syarat.

\section{SARAN}

Adapun saran yang dapat penulis sampaikan, yaitu:kepada pengelola Pasar Kreneng diharapakan untuk mempertahankan keadaan air bersih bila memungkinkan perlu dilakukan pengujian kualitas air untuk kebutuhan higiene sanitasi dilakukan enam (6) bulan sekali, mempertahankan keadaan kamar mandi dan toilet bila memungkinkan diharapkan untuk melakukan perbaikan dengan memisahkan toilet laki-laki dan perempuan, menyediakan sabun pada tempat cuci tangan serta meningkatkan pemeliharaan terhadap kebersihan kamar mandi dan toilet, melakukan perbaikan pada TPS dengan menambahkan penutup, melakukan pemilahan sampah basah dan sampah kering disertai dengan pengolahan sampah dengan metode 3R (reduce, reuse, recycle) dan memperhatikan kebersihan lingkungan di seluruh area pasar, mempertahankan keadaan sarana pembuangan air limbah, bila memungkinkan diharapkan juga untuk melakukan pengujian kualitas air limbah secara berkala setiap enam bulan sekali dan melakukan pengolahan air limbah dengan membangun instalasi pengolahan air limbah (IPAL), tetap mempertahankan dan meningkatkan kebersihan tempat cuci tangan, melakukan upaya pengendalian vektor atau binatang penular penyakit dengan melakukan penyemprotan terhadap lalat, nyamuk, dan kecoa serta melakukan upaya pengendalian tikus minimal dua kali setahun.Kepada pedagang di Pasar Kreneng, diharapkan untuk secara bersama-sama dengan pengelola pasar menjaga kebersihan fasilitas sanitasi pasar demi terciptanya kondisi pasar yang bersih, aman, nyaman dan sehat guna melindungi masyarakat dari risiko penularan penyakit dan gangguan kesehatan yang berasal dari pasar. 


\section{DAFTAR PUSTAKA}

1. Peraturan Menteri Kesehatan No. 17 Tahun 2020 tentang Pasar Sehat. (2020).

2. Kusnaedi. Mengolah Air Gambut dan Air Kotor untuk Air Minum. (Puspa Swara, 2004).

3. Chandra, Budiman. Ilmu Kesehatan Masyarakat dalam Konteks Kesehatan Lingkungan. (Penerbit Buku Kedokteran EGC, 2012).

4. Jana, I. Wayan, Mardani, N. K. \& Suyasa, I. W. B. Analisis Karakteristik Sampah dan Limbah Cair Pasar Badung dalam Upaya Pemilihan Sistem

Pengelolaannya. ECOTROPHIC J. Ilmu Lingkung. (Jurnal Environ. Sci.2 (1), (2006).

5. Noviyani, E., Dupai, L. \& Yasnani. Gambaran Kepadatan Lalat di Pasar Basah Mandonga dan Pasar Sentral Kota Kendari Tahun 2018. J. Ilm. Mhs. Kesehat. Masy.3, 1-9 (2018).

6. Sumantri, Arif. Kesehatan Lingkungan. (Kencana Prenada Media Group, 2013).

7. Ristiyanto, Sustriayu N, Soenarto N, Haripurnomo K, D. T. Tikus, ektoparasit, dan penyakitnya. (Balai Besar Penelitian dan Pengembangan Vektor dan Reservoir Penyakit (B2P2VRP), 2002).

8. Ditjen PP \& PL. Pedoman Pengendalian Tikus Khusus di Rumah Sakit. (2008).

9. Komariah, Seftiani Paramita. Pengendalian Vektor. J. Kesehat. Bina Husada6 (1), (2010).

10. Hanag Soejodi. Pengendalian untuk Suatu Tindakan Karantina. J. Kesehat. Lingkung.2 (1), (2005). 